\title{
SOCIAL FINANCE INSTRUMENTS TO SUPPORT B40 AND MICRO-ENTERPRISES: DETERMINANTS OF ISLAMIC FINANCIAL INSTITUTION EMPLOYEES' ACCEPTANCE
}

\author{
MUHAMMAD FARIS ABD RASID ${ }^{1}$ \\ ZURAEDA IBRAHIM ${ }^{2}$, * \\ ZAFIRUDDIN BAHARUM ${ }^{2}$
}

Received: 5 April 2018 / Revised: 31 July 2019 / Accepted: 5 August 2019

(C) 2020 Faculty of Business and Accountancy, University of Malaya. All rights reserved.

\section{A B S T R A C T}

Research aim: This paper identifies factors that significantly influence the acceptance of employees from the Islamic Financial Institution of Social Finance Instruments (SFIs) as tools to provide affordable financing to B40 and micro-enterprises.

Design/ Methodology/ Approach: A well-structured survey questionnaire, distributed to 197 IFI employees working in institutions that are located in Selangor and listed by the Central Bank of Malaysia.

Research finding: Overall, the findings showed that awareness and knowledge have strong and significant relationships with acceptance, whereas, for demographic factors, only education level and monthly income have a significant relationship with the level of acceptance of SFIs among IFI employees.

Theoretical contribution/ Originality: The results revealed that the acceptance level of SFIs among IFI employees has a significant and robust relationship with the level of knowledge that employees possess. This is consistent with the Theory of Planned Behaviour, where individuals' actions depend on their belief about a particular situation when making decisions on behalf of the institution in which they are employed. Therefore, before any IFI implements the SFI concept, they should be proactive in increasing the level of acceptance by taking the steps needed to equip employees with adequate knowledge to ensure that the objectives of SFIs can be achieved.

Practitioner/ Policy implication: In the context of this study, awareness and knowledge among the employees of IFIs must be created in advance for any new concept to be readily accepted before the products been introduced to the public.

Research limitation/ Implication: Due to the low response rate, future studies could include all IFIs throughout Malaysia along with other SFIs-related individuals such as investors and educators.

Type of article: Research paper

Keywords: Social Finance Instruments, B40, Micro-Enterprises, Islamic Financial Institutions, Employees' Acceptance

JEL Classification: G21

\section{Introduction}

Poverty is a severe issue in this globalised era. The World Bank (2018) raised concerns about achieving the goal of ending poverty by 2030 and pointed to the need for increased pro-poor investments. The decline in poverty rates has slowed,

\footnotetext{
${ }^{1}$ Accountant General's Department of Malaysia, Ministry of Finance Complex, 62594 Putrajaya, Malaysia

2 Faculty of Accountancy, Universiti Teknologi MARA, 42300 Bandar Puncak Alam, Selangor, Malaysia

* E-mail for corresponding author: zurae229@uitm.edu.my
} 
with the percentage of people living in extreme poverty globally falling from 11 per cent in 2013 to 10 per cent in 2015, reflecting steady but slow progress. An estimated 767 million people were living below the international poverty line of US\$1.90 per person a day in 2016 (World Bank, 2016). The World Bank's (2017) mission consists of two ambitious but achievable goals to end extreme poverty by 2030. They plan to reduce the percentage of people living below US $\$ 1.90$ per person a day and to boost shared prosperity by fostering 40 per cent of the income growth for the poorest in every country. According to President Jim Yong Kim, in order to end poverty by 2030, building human capital is crucial, significant investments are needed to reach the remaining poor (World Bank, 2018).

Meanwhile, throughout the developed world, the UN needs to find answers for a more egalitarian distribution of income. There is a need to achieve both a decline in poverty as well as an egalitarian distribution of income for the developing world. On average, Muslim-majority countries are generally poorer than in other countries. According to Haneef, Pramanik, Mohammed, Dahiru, and Amin (2013), 31 per cent of the total population of these countries live in poverty and in the 57 member countries of the Organisation of Islamic Cooperation (OIC), many people live on average incomes below US $\$ 1.25$ per day. Shaikh, Ismail, and Shafiai (2017) point out that there is an enormous need for the development of infrastructure and spending in the largely income-poor Muslim world since the size and the scope of the formal-sector of financial institutions in these countries are small and concentrated.

Malaysia, a country with a population of more than 32 million multi-ethnic people (Department of Statistics Malaysia, 2018b), has successfully transformed from a poor country into a middle-income country. The Poverty Line Index (PLI), the measurement of poverty in Malaysia, was introduced in June 1977 based on the 1973 Household Expenditure Survey (HES). The government's national policies towards poverty eradication efforts have been given high priority since Malaysia developed its own poverty line index. A household is considered to be living in poverty when its total income is below the established poverty line.

The Economic Planning Unit, Malaysia (EPU), provides the guidelines for policymakers to identify the poor and monitor their incidence (United Nations Development Programme (UNDP) Malaysia, 2007). Mustapa, Mamun, and Ibrahim (2018) explained that, in Malaysia, poverty is measured by using the poverty line index (PLI), a quantitative money metric measure. When the household monthly gross income is below the PLI, the household is considered poor. In peninsular Malaysia, households with gross monthly income below RM760 and RM460 are considered to be extremely poor and absolutely poor, respectively. Based on average monthly household income, 40 per cent of Malaysian households have an equivalent monthly income of RM2,848, or below $\mathrm{RM} 3,000$, and are classified as belonging to the low-income households or B40 (bottom 40 per cent) group (Department of Statistics Malaysia, 2017).

Due to the limitation of government funding (Khan, Tahmazov \& Abuarqub, 2009), and the unstable economic situation (Jones, 2010), social finance instruments (SFIs) have been introduced as one of the products of Islamic financial institutions to assist the underprivileged. This initiative is also intended to encourage the involvement of Islamic Financial Institutions (IFIs) in assisting the 
needy, as well as aiming to reduce income inequality and thereby creating a better socio-economic balance. SFIs can play a crucial role to overcome social challenges. The use of SFIs is in line with the Value-Based Intermediation (VBI) introduced by the Central Bank of Malaysia and with the Sustainable Development Goals (SDGs) developed by the United Nations. This is also a reflection of the rising trend in sustainable banking that places the planet and the people before profits, where investors are becoming more aware of the impacts of short-term wealth goals and the use of resources. Moreover, ethical finance and investment activities have shown an increasing pattern of environmental awareness since 2017, with more than 30 per cent of global assets in socially responsible investments (SRIs) (Ziyaad, 2017). Aziz and Mohamad (2016) argued that the IFIs, social policymakers, Islamic charity organisations (ICOs) and Islamic social enterprises (ISEs) need to take advantage of existing entities by identifying all the potential Islamic sources of funding. Coupled with efficient management, the process of alleviating poverty could be more effective in reducing social inequality and solving social problems.

To ensure the objectives of the SFIs can be achieved, employees of IFIs have critical roles to play, since they are the ones who will support and execute the implementation of the SFIs. Currently, there are still unresolved debates among the public on the IFIs products and their employees. To overcome this issue, and since the use of SFIs in Malaysia is still in the infancy stage, employees attached to the IFIs need to understand and appreciate the roles of SFIs in mitigating social challenges. In fact, without their assistance and cooperation, it would be difficult to realise any of the organisation's objectives (Muda, Rafiki, \& Harahap, 2014). First, employees of the IFIs must accept and embrace the concept and products of SFIs before they can introduce them to potential customers, and this is impossible if they do not understand or have knowledge of the SFIs. Therefore, it is vital that the employees are aware of, understand, and are knowledgeable about SFIs so that these new products can be offered to the underprivileged (Ziyaad, 2017). Furthermore, IFI employees' acceptance is vital because their acceptance will enable them to be more transparent in dealing with their customers. They could look at the beneficial impact of their customers' or investors' investments on the greater community (Benedikter, 2011). Moreover, knowledgeable and skilful employees always contribute to the positive environment of an organisation (Linder \& Wald, 2011).

Consistent with these arguments, this study aims to investigate and identify factors that significantly influence IFI employees' acceptance of SFIs as a tool to provide affordable financing to the B40 group and micro-enterprises. A total of 197 well-structured questionnaires, developed following the methodology of Abuarqub and Phillips (2009), Hassan (2014), Haneef et al. (2013), Aziz and Mohamad (2016), Razinah, Zain, and Adawiah (2017), and Roose and Bishnoi (2012) were distributed to IFIs employees in the Klang Valley area. The factors considered in this study were: (i) awareness, (ii) knowledge, and (iii) demography. The findings from this study are expected to contribute to the development of Islamic social finance for Islamic financial institutions, particularly in Malaysia.

The remainder of the article is organised as follows: Section 2 briefly describes the Islamic Financial Institutions and Social Finance Instruments (SFIs); Section 3 summarises the development of hypotheses; Section 4 details the research method; 
Section 5 presents the results and discussion; and, finally, Section 6 provides the general conclusions.

\section{Literature Review and Hypothesis Development}

\subsection{Islamic Financial Institutions and Social Finance Instruments}

According to Razinah, Zain, and Adawiah (2017), Social Finance Instruments (SFIs) include waqf, sadaqah, zakat, Islamic microfinance, sukuk and takaful; and for co-operative products, SFIs include Kafala (Guarantee) and Qard (Loans). Islamic financial services related to the SFIs provide social-based financing investments which benefit the society at large as well as the individual.

SFIs can lead to three additional features of social banks; namely responsibility, sustainability and transparency that make them unique in the financial world (Benedikter, 2011). As for responsibility; social banks expect borrowers to use the loans responsibly for the greater purpose, and they care about mutual responsibility since they know their customers personally. Their activities exclude risky investments or reckless speculation. Social banks also want their money to be invested ethically and wisely. Meanwhile, sustainability relates to the demand for social banks to focus more on the long-term effects of money instead of creating short-term profits on which most mainstream banks are focused. They also aim to develop the society, individuals, and the environment by making investments in small projects that may give positive effects over time.

In relation to transparency; social banks know their money flow or loans to their customers. They also look at the impact of their investment on the greater community, for example, whether or not the money lent is used to help people, to protect the natural environment, or to generate a better life for others. Other than that, social banks provide full accounts to all their depositors of how their money is used. This means that the depositors know exactly what their money is used instead of simply earning interest at the bank.

Haneef et al. (2013), in their study, stated that one of the products offered by SFIs is Integrated Waqf-based Islamic Microfinance (IWIM). IWIM and its components have received full support from all relevant stakeholders, such as government agencies and non-profit organisations (NGOs), as an essential mechanism to alleviate poverty. The programme provides affordable finance and is dedicated to human development and poverty alleviation. In order for the SFIs to be accepted, it is essential to create awareness among the IFIs and the public. An effective education program is important so that the public can understand the rationale of the instruments.

Subsequently, the SFIs are also consistent with the strategy introduced by the Central Bank of Malaysia, known as Value-Based Intermediation (VBI). VBI was developed to strengthen the roles and impact of IFIs, with the understanding that the institutions should focus more on a socially responsible banking environment. In another perspective, Aziz and Mohamad (2016) stated that Islamic social business (ISB), which is consistent with the SFI concept, is a new operational framework; well-set as an instrument that can reduce social inequality, solve social problems and also efficiently alleviate poverty based on Islamic concepts. Its principles adhere to the Quran and Sunnah as well as the contemporary social welfare philosophies such as social business, social enterprise and augmented 
stakeholder theory. They opined that, with an efficient management system, the process of poverty alleviation could minimise social problems such as issues related to the environment, literacy, health, and shelter. IFIs, social policymakers, Islamic charity organisations (ICOs), and Islamic social enterprises (ISEs), therefore, should initiate proper guidelines to identify various potential Islamic sources of funding to alleviate poverty, reduce social inequality, and overcome social problems. The Islamic social business model is illustrated in Figure 1.

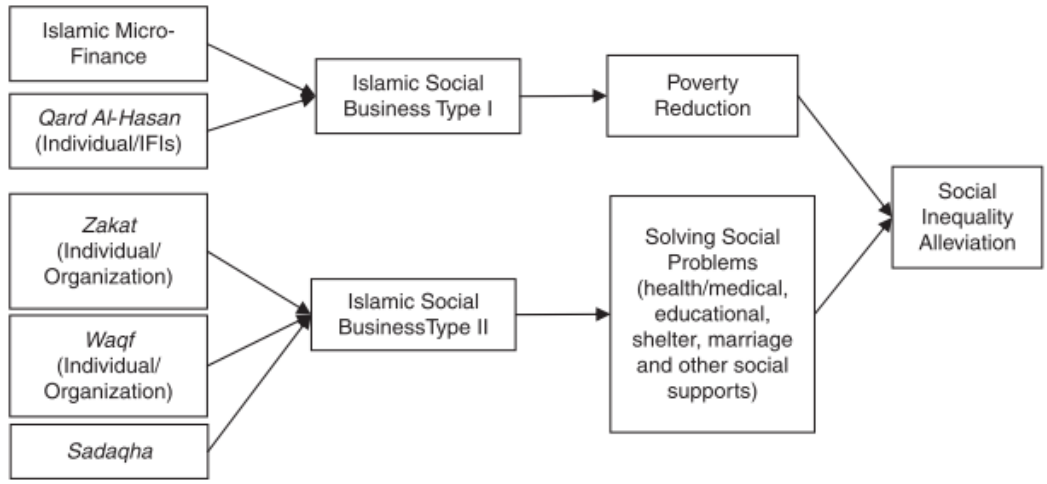

Figure 1. Islamic Social Business (ISB) Model

Source: Islamic social business to alleviate poverty and social inequality (Aziz \& Mohamad, 2016)

The model illustrates how waqf, sadaqah and zakat can be used to solve social problems, specifically related to educational, health or medical, and shelter issues, for the B40 and micro-enterprises. The IFIs are seen to be in a better position to uphold the role of social banks in ensuring that social and economic welfare is improved through the equitable distribution of income and wealth, the achievement of environmental balance and social justice, and the promotion of economic development for religious commitments. The superiority of Islamic financial management has encouraged the Islamic finance industry to experience continuous development and growth all over the world where the key objective is to serve humankind instead of just to sustain in a challenging environment and earn a profit. IFIs should work hand-in-hand with the government to take responsibility for overcoming the social problems of the poor and underprivileged people in society. IFIs can expand their financial instruments and mechanisms to encourage entrepreneurship among the poor, and, consequently, alleviate poverty and reduce social inequality (Aziz \& Mohamad, 2016).

Empirical analysis on the current practices of Qard Al-Hasan by Islamic banks, Zakat collection and distribution, as well as the utilisation of the Waqf fund by Islamic charity organisations have given further insights into the potential of ISB operations. A study carried out by Shaikh (2017) suggested a framework in which equity financing could be used to fund micro-enterprises that will employ poor people with relevant skills. A study by Rizzi, Pellegrini, \& Battaglia (2018) found that SFIs are evolving rapidly in Europe. However, academic literature on the structures of legitimisation that characterise the development of social finance has 
been limited. Existing studies on this issue have addressed the following gaps: (i) conceptualising social finance (SF) as a pre-paradigmatic field where the leading SF institutions have spontaneously adopted different investment rationalities and logics to achieve positive social impact through financing and banking activities; (ii) discussing dominant institutionalisation patterns and empirically exploring the institutionalisation of SF at the organisational, inter-organisational and institutional levels. A sample of $17 \mathrm{SF}$ institutions in three European countries, such as Ireland, Italy and the UK, was examined.

The analysis highlighted that two forms of SF, namely social impact investment and ethical banking, guide the institutionalisation and paradigm building process These two forms assume the production of social impact, such as impact on society, environment and sustainable development, as a trait distinguishing them from commercial financial approaches, but differ in terms of business models and products and services provided to customers (Rizzi et al., 2018).

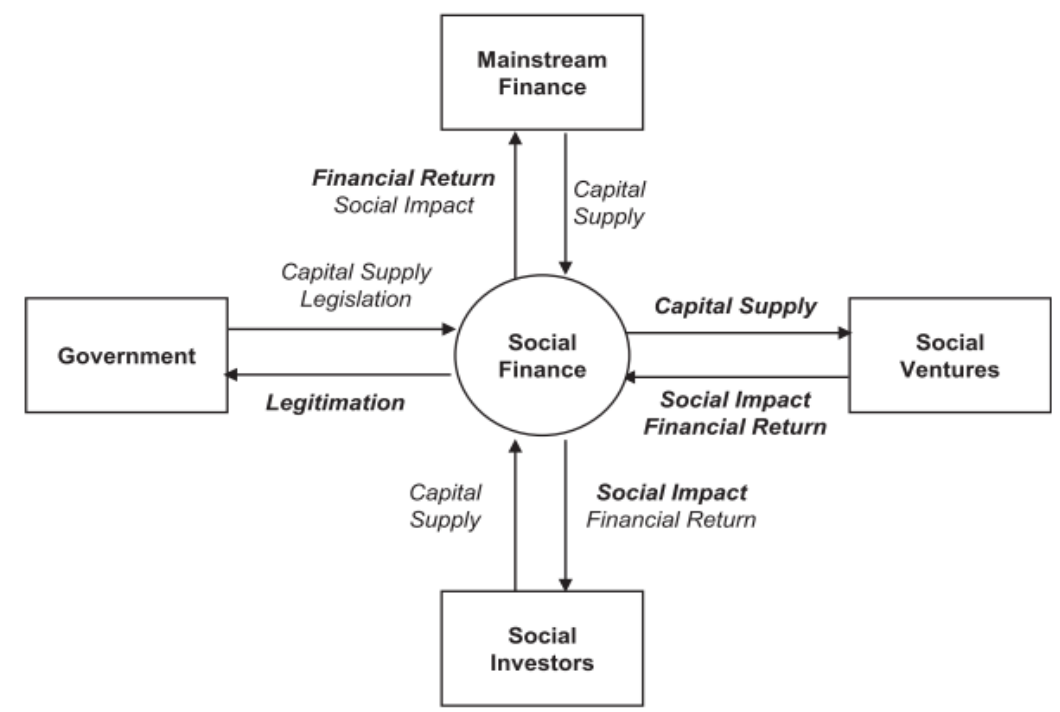

Figure 2. Main Categories of Actors in Social Finance

Source: The structuring of social finance: Emerging approaches for supporting environmentally and socially impactful projects (Rizzi et al., 2018)

Figure 2 presents the main categories of actors in SF developed by Rizzi et al. (2018). Their results served as a foundation for SF as a new paradigm in support of a reformed future global economy, which is more responsive to social challenges. Consistent with Rizzi et al. (2018), a study done by Zain and Ali (2017) argued that Islamic SFs must be utilised in protecting and preserving the Shariah requirements in order to be impactful. Their study reviewed the practices of the Islamic SF applied in OIC member states and found that the member states are already on the right track in implementing Islamic social finance. They also stated six essential matters, namely, (i) deen (religion), (ii) nafs (life), (iii) nasl (progeny), (iv) 'aql (intellect), (v) maal (property) and (vi) ard' (honour) as important elements 
for alleviation of mischief or evil (mafsadah) in the society. It is also crucial in preserving interests or good (maslahah) in the public. They highlighted problems in implementing Islamic social finance and its instruments, which included: the relevant laws applicable for each instrument of Islamic social finance, the issues on implementing Islamic social finance or its instruments, the detriments which can cause failure to the success of Islamic social finance in preserving and protecting Maqașid Al-Shariah, and suitable mechanisms or models in the implementation of Islamic social finance.

A large body of literature exists on IFI issues, and matters concerning IFI products have been widely debated by the public, academics, and IFI stakeholders. However, as mentioned earlier, the issues remain unresolved. The existing literature, as asserted above, has dealt mainly with IFIs and SFIs in developed countries; therefore, it is important to study SFIs in Malaysia and from a different angle, specifically with an emphasis on the issue of employees' acceptance. This study focused on the employees of Islamic Financial Institutions because their acceptance of the SFIs concept is vital in facilitating the SFIs agenda.

Additionally, to explain the IFI employees' acceptance of the SFIs, the Theory of Planned Behaviour (TPB) has been adopted. This states that an individual will usually evaluate all the consequences of his action before he decides whether to proceed or otherwise when he has been authorised to decide on behalf of a company. Typically, his action will be influenced by his beliefs about the specific situation; and beliefs are generally influenced by a person's prior knowledge of the situation.

\subsection{Hypotheses Development}

Previous studies had examined the acceptance of SFIs by financial institutions, businesses or companies, and individuals worldwide. SFIs have been introduced widely, especially in the United Kingdom (UK) to alleviate social problems since 2007. Social finance has managed to improve the wellbeing of individuals with complex needs. It has also managed to address the challenges faced by low and middle-income countries (Social Finance Organisation in United Kingdom, 2017). However, when looking into the significant impact of SFIs in developing countries, specifically Malaysia, there are still many issues that remain unresolved.

Therefore, this study concentrated on three factors; i.e. awareness, knowledge and demographics, that can influence the acceptance level of SFIs among the IFI employees in Malaysia, specifically in Selangor. The following sections discuss the development of the hypotheses relating to the variables for the acceptance of SFIs by the financial institutions' employees examined in this study.

\subsubsection{Awareness}

Awareness changes how people think about their lives, and it raises expectations about what is possible (World Bank, 2017). The World Bank has engaged with partners at the local, regional and global levels to raise awareness about the progress made and actions needed to end poverty. Roose and Bishnoi (2012) argued that an informed and enlightened society assists the process of shaping the broader development of the finance community. Samad (2014) stated in his article that an awareness campaign was essential to ensure that the IMF programme in 
India to reduce poverty, empower women financially, and inculcate a culture of savings, could achieve greater involvement of the people. The World Bank also stated that the bank implements various strategies to ensure that their senior management is aware of the impacts of the procurement activities, which will then enable the bank to address its fiscal, social, and environmental impacts simultaneously (World Bank, 2016). The study by Shaikh et al., (2017b) also concluded that it is important to create social awareness before creating the right kind of waqf at the right place.

In a different situation, Hassan (2014), in his study, also examined the level of awareness on environmental issues among his target respondents to uplift the Islamic microfinance groups members and the potential for LCR management through the united action of the groups. Thaker (2018) gathered experts' opinions and recommendations on the suitability, applicability, and prospects of the ICWME-I model. Their findings revealed that legal challenges and public awareness are considered as potential challenges that might arise in implementing the ICWME-I model. Consequently, Jones (2010), in his article, also stated that awareness of the diverse nature of institutions that exist in human societies is important as it leads to an understanding of the mechanisms that allow community collaboration. Haneef et al. (2013) conducted a study in Kuala Selangor, Malaysia, using 102 sahabat (clients) from Amanah Ikhtiar Malaysia (AIM) to examine the relationship among five constructs, namely Waqf resources, IsMF, Takaful, human resources, and poverty alleviation. They also examined respondents' awareness level of the specific programmes. Their findings revealed very negative results. The awareness level of the respondents regarding Islamic microfinance was low. They further argued that, for acceptance purpose, awareness among the recipients must be created in advance among the clients of microfinance about the existence and nature of Islamic microfinance.

Oseni, Adewale, and Zain (2016) examined the perceptions of retail customers on the dispute resolution clauses and jurisdiction clauses contained in the governing law on Islamic finance contracts in Malaysia. Their study revealed that there is a statistically significant direct effect of dispute resolution clauses in Islamic finance contracts on the legal awareness and understanding of the customers and an indirect effect on the customers' dispute resolution channels. In another context, according to Radun, Nilsonne, Radun, Helgesson, and Kecklund (2019), company employees were participants in the field of traffic safety that discussed ethical and methodological implications when testing products, technology, or paradigms that were developed. The research in traffic safety conducted through company employees to indicate the level of awareness of procedures and voluntary participation showed that, where the employees were hired from an in-house database, they (.13 per cent) were seldom aware of the procedures and voluntary participation. Contradictorily, Montargot and Lahouel (2018) found that, when using IT innovation, employees' acceptance of technological change is paradoxical and shaped by a continuous process. The key to successful and sustainable IT implementation has been demonstrated as being front-line staff awareness and acceptance. In the present study, the focus was on the IFI employees' acceptance and awareness which could encourage the acceptance of SFIs. These previous studies, however, provided insufficient 
evidence to claim that awareness had any effect on acceptance level. Therefore, following Haneef et al. (2013), the following hypothesis is applied to test the relationship between awareness and the acceptance level.

H1: There is a relationship between the awareness of IFI employees and their acceptance of SFIs.

\subsubsection{Knowledge}

Prior knowledge of IFI products is important to ensure that consumers can accept the products. Fianto et al. (2017) found that clients' knowledge of Islamic microfinance had a significant impact on their income. Perren (2000) examined micro-the growth of enterprises and concluded that the owner-managers' intimate knowledge about their businesses empowered them to think creatively about growth opportunities. Ahmad (2012), in his study of the main problems and constraints faced by micro-, small and medium-sized entrepreneurs (MSMEs) in the Kingdom of Saudi Arabia, highlighted that inexperienced entrepreneurs in the field of business, particularly entrepreneurs lacking technical knowledge, was one of the factors for business failure. Subsequently, Alessia and Boiardi (2017) argued that, in order to tackle societal challenges, to make more effective use of public resources, and to promote more sustainable and environmental-friendly growth in Europe, relevant knowledge is needed. A study by Gait and Worthington (2008) reviewed the attitudes, perceptions and knowledge of consumers about Islamic financial products and services and suggested that future research in Islamic finance should include attitudes, perceptions and knowledge of Islamic financial products and services to aid the decision making of policymakers, consumer interest groups, business companies, and financial institutions.

From another perspective, Scharrer (2015) stated that a better understanding of the motivation and intention of employees to accept and act according to a local Code of Conduct is important, since these Codes may impact the employees' ethical behaviour. Furthermore, knowledge is an important factor influencing the intention of individuals to behave ethically. Knowledge has also been shown to be a predictor of employees' acceptance and participation concerning a corporate Code of Conduct. Tayal, Upadhya, Yadav, Rangnekar, and Singh (2018) studied transformational leadership and employee acceptance of change while establishing the mediating effects of innovative behaviour. The moderating effect of the use of information technology (IT) resulted in a positive association between knowledge and employee innovative behaviour. This is aligned with Park, Rhoads, Hou, and Lee (2014) who found that professionals with diverse backgrounds can help to contribute to the accrual of knowledge of technology use in work practices and the strengthening of ecological validity. The study employed the framework of the technology acceptance model (TAM) to identify the factors that affect employees' acceptance and use of teleconferencing systems for work-related meetings in business settings. In the present study, it is expected that IFI employees' acceptance and knowledge would encourage greater acceptance of SFIs. Discussions of prior studies regarding the importance of knowledge, as mentioned in this section, justify the view that prior knowledge is crucial to ensure that the IFIs can achieve their objectives. Consistent with findings 
of previous studies regarding knowledge and understanding of Islamic SF, specifically on the use of the products to assist the B40 where microfinance is not available, the following hypothesis is developed to test the relationship between knowledge and acceptance level of IFIs' employees on the SFI concept.

H2: There is a relationship between IFI employees' knowledge of SFIs and acceptance of the SFIs.

\subsubsection{Demography}

Studies revealed that demographic factors influence the acceptance level of people to certain concepts, products, and attitudes. Sherif and Shaairi (2013) examined various identified and available economic and socio-demographic variables in determining the consumption of family takaful. Their study found that income level and education level are among the factors that are positively related to takaful demand. McCannon (2014) examined the impact of finance education on the social preferences and behaviours of individuals. He highlighted that education in finance promotes pro-social choices that generate wealth, even when external incentives are absent.

Al-sultan (1999), in his study, revealed that age, income, and occupation play significant roles in deciding which banking system to choose in Kuwait. Kuwait has a dual banking system to choose from, offering both conventional and Islamic banking. Since more people follow Islamic teachings, there is a higher proportion of clients who deal with Islamic banking. Consistent with previous arguments, Milfont and Gouveia (2006), Paetzold, Busch, and Chesney (2015), Ostrom et al. (2010) and Cheah and Phau (2011) also highlighted in their papers that sociodemographic variables such as age, education level, and gender affect their dependent variables.

In a different context, the demographic profile of the respondents, including variables such as gender, age and working experience, were used to study transformational leadership and employee acceptance to change while establishing the mediating effects of innovative behaviour and the moderating effect of the use of information technology (IT) (Tayal et al. 2018). Park et al. (2014), who studied the factors associated with the objective and physical properties of a system, suggested that individuals may have different perceptions towards the system because of their demographic backgrounds. They also suggested that a more comprehensive understanding of the potential roles of teleconferencing systems along with the individual and task characteristics in the use of communication technologies in the workplace is needed.

This might be applied not only to the present study but also to other TAM studies in general. In this study, the IFI employees' acceptance and demography play roles that might encourage the acceptance of SFIs practice in this country. As there is little empirical evidence indicating a clear relationship between demographic variables and the level of IFI employees' acceptance of the SFIs concept, this study will investigate the following hypothesis:

H3: There is a relationship between the demography of IFI employees and the acceptance of SFIs. 


\section{Methodology}

The main objective of this study is to investigate and identify the factors that significantly influence IFI employees' acceptance of SFIs as potential tools to provide affordable financing to the B40 population and micro-enterprises. This study focused on Islamic Financial Institutions because they are the main contributors facilitating entrepreneurial activities that are able to create positive impacts with a balanced consideration between social aspects and commercial aspects based on the provision of a financial solution (Bank Negara Malaysia, 2018b). Additionally, only IFIs offer innovative products such as Waqf House Financing and social capital such as Sadaqah House (Bank Islam Malaysia Berhad (BIMB), 2017, pg. 22).

The target respondents are employees of the IFIs because they are the leading players in achieving this SFI agenda. Prior studies have been mainly related to issues of employees' participation, perceptions, and commitments. Even in different research settings, they have reported that in ensuring an organisation's policy could be successfully implemented, the support of employees is crucial (D'Ortenzio, 2012). Since SFIs are new products to be offered by IFIs to the underprivileged, and they aim to support a real economy rather than creating an unsustainable and superficial financial system (Ziyaad, 2017), the IFI employees should not only be aware of but should have some in-depth knowledge of these products to ensure their successful implementation.

To ensure that the results produced are significant for a study, a wellstructured survey questionnaire has been developed following the methodology of Abuarqub and Phillips (2009), Hassan (2014), Haneef et al. (2013), Aziz and Mohamad (2016), Razinah, Zain, and Adawiah (2017), and Roose and Bishnoi (2012). A questionnaire, rather than interviews and observation, was adopted for this study because it was more feasible, given the constraints of time and resources. The results are expected to give the IFIs a clearer picture of the current situation regarding the use of SFIs as affordable financing for the B40 group and micro-enterprises in this era of globalisation. The questionnaire was divided into four sections; questions relating to awareness that influence the IFI employees use of SFIs; knowledge and understanding of the IFI employees in using SFIs; respondent's acceptance level of SFIs used by the IFIs; and respondents' demographics in terms of investment or contribution, and frequency of involvement with SFIs. All the questions were structured questions. For Section A to Section $C$, answers were on a categorical scale using a 5-point Likert scale (1=Strongly Disagree, 2=Disagree, 3=Uncertain, 4=Agree, 5=Strongly Agree). In Section $\mathrm{D}$, which is background information, answers were based on the selection from the alternatives provided.

A list of selected local Islamic banks in Malaysia was developed by analysing the branches of banks, located according to states, through their annual reports and bank websites. The total number of Malaysian Islamic banks in the country in the year 2018 was 1,923. In all, 197 sets of self-administered questionnaires were distributed by hand to respondents in Klang Valley who were employees of the selected local Islamic banks in Selangor, followed by a personal approach or phone calls as reminders. Respondents were not drawn from any specific department in the banks, but rather from those IFI employees who deal with customers or clients, 
in general. Banks in the Klang Valley were selected because the highest number of Islamic banks is found in this area (744 of the total 1,923).

\section{Results and Discussions}

As Table 1 below shows, a total of 197 questionnaires were distributed to IFI employees, but only 94 responses were received, representing 48 per cent of the overall sample. Nevertheless, this number meets the rule of thumb mentioned by Roscoe (1975) as cited in (Hill, 1998) that samples of 30 or more are recommended in a research study. Details of the response rate in Table 1. In the next section, the demographic characteristics of the sample in this study are described.

Table 1. Response Rate

\begin{tabular}{lcc}
\hline & Number & Percentage \\
\hline Total questionnaires collected/ complete & 94 & 48 \\
Total collected but incomplete & 0 & 0 \\
Total missing/not returned & 106 & 54 \\
Total questionnaire distributed & 197 & 100 \\
\hline
\end{tabular}

\subsection{Demographic Characteristics of the Sample}

This section describes the demographic characteristics of the respondents who returned completed questionnaires. Table 2 shows percentages of respondents according to demographic variables of age, level of education, level of position in the bank, and their monthly income. Additionally, the table below also presents the contribution that the respondents had made through Sadaqah, waqf and zakat and their frequency of contribution of these types of SFIs. Table 2 shows that the highest frequency age group of the respondents who are involved with SFIs is the group aged 31 to 45 years old, which represented 57.4 per cent, followed by those aged 46 to 60 years old, which represented 23.4 per cent of the respondents. The table also shows that the highest frequency of respondents (36.2 per cent) have a diploma or A-Level, followed by those with a bachelor's qualification (27.7 per cent).

Table 2. Demographic Profile of IFI Employee Respondents

\begin{tabular}{lcc}
\hline Profile & Frequency & Percentage \\
\hline Age (Years Old) & & \\
30 or below & 18 & 19.1 \\
31 - 45 & 54 & 57.4 \\
46 - 0 & 22 & 23.4 \\
Above 60 & - & - \\
Level of Education & 6 & \\
Postgraduate (Master/PhD) & 3 & 6.4 \\
Professional Qualification & 26 & 3.2 \\
Bachelor & 34 & 27.7 \\
Diploma / A-Level & 25 & 36.2 \\
Others & & 26.6 \\
Position Level & - & \\
Board of Director & 1 & - \\
Chief Officer & 15 & 1.1 \\
Manager & 14 & 16.0 \\
Supervisor & & 14.9
\end{tabular}


Table 2. Continued

\begin{tabular}{lcc}
\hline Profile & Frequency & Percentage \\
\hline Others & 64 & 68.1 \\
Monthly Income & 64 & 68.1 \\
RM10,000 and below & 13 & 13.8 \\
RM10,001 - RM30,000 & 16 & 17.0 \\
RM30,001 - RM50,000 & 1 & 1.1 \\
Above RM50,000 & & \\
Heard about SFIs such as Sadaqah, waqf and zakat & 84 & 89.4 \\
Yes & 10 & 1.6 \\
No & & \\
Invest or contribute in SFIs & 65 & 69.1 \\
Sadaqah & 52 & 55.3 \\
Waqf & 86 & 91.5 \\
Zakat & 15 & 16.0 \\
Others & & \\
Frequently invest in SFIs & 8 & 8.5 \\
Daily & 15 & 16.0 \\
Every Week & 70 & 74.5 \\
Every Month & 25 & 26.6 \\
Every Year & 1 & 1.1 \\
Others & & \\
\hline
\end{tabular}

The majority of the respondents (68.1 per cent) are employed in the 'others' category, such as executives and clerks, followed by 'manager' (16.0 per cent). No respondent was a member of the Board of Directors, and only a few held posts as Chief Officer, which reflects the small number of positions available for such posts. Since this study focused on IFI employees, these results showed that SFIs are relevant and have their support. The category for monthly income among employees with the highest frequency, as shown in the table above, was RM10,000 and below, which accounted for 68.1 per cent, followed by RM30,001 - RM50,000 which represented 17.0 per cent. The demographic results also show that 89.4 per cent of respondents have heard about SFIs such as zakat, waqf and sadaqah, and 91.5 per cent paid zakat, 69.1 per cent contributed to sadaqah while 55.3 per cent had made contributions to waqf. The majority of the employees (74.5 per cent) invest monthly in some form of SFI while 26.6 per cent made an annual investment. Some employees made more frequent investments: 16 per cent invested weekly and 8.5 per cent did so daily.

\subsection{Reliability Test}

In measuring the factors that influence the acceptance of SFIs among the IFI employees in Malaysia, the study used a total of 25 statements. There are seven statements related to awareness, nine statements related to knowledge, and nine statements related to the acceptance level of SFIs among the employees. The statements were tested according to their dimensions of measurement for reliability or consistency using Cronbach's Alpha test. If the Cronbach Alpha value is high, the statements are consistent and, therefore, reliable. A value of above .8 is preferable. The results of this test are summarised in Table 3 . The Cronbach Alpha values for all the dimensions are high and above the preferred minimum value of .8. The value ranges from .943 (awareness) to .963 (knowledge), 
indicating that the various statements reliably measure the perceptions of the respondents on the three dimensions being measured. The next section focuses on the acceptance of SFIs among the IFI employees in Malaysia. The respondents' answers were measured based on a 5-point Likert scale; 1 represents 'Strongly Disagree' and 5 represents 'Strongly Agree'. The descriptive statistics of the scores are presented and discussed separately for each dimension, beginning with awareness of SFIs, and ending with the demographic information.

Table 3 Cronbach's Alpha by Dimension

\begin{tabular}{lcc}
\hline Dimension & No. of statements & Cronbach's Alpha \\
\hline Awareness & 7 & .943 \\
Knowledge & 9 & .963 \\
Acceptance Level of IFIs' employees on SFIs & 9 & .962 \\
\hline
\end{tabular}

\subsection{Awareness of Social Finance Instruments}

Table 4 below presents the means and standard deviations of scores on respondents' awareness of the SFIs, arranged in descending order of size (declining agreeability). Considering all the seven statements together, the mean score of 3.52 indicates that, on average, the respondents indicate a more positive level of awareness of SFIs, closer to 'agree' on the Likert scale. From the results shown in the table above, it can be seen that the respondents are generally aware of SFIs (overall mean=3.521).

Many of them have both heard about SFIs before they make their contributions or investments (Mean=3.46) and know the purpose and/function of the SFIs (Mean=3.51). The mean for the statement Islamic Financial Institutions need to provide affordable financing through Social Finance Instruments that are Shariahcompliant (Mean=3.67) indicates a relatively high level of agreement. They also agree that Social Finance Instruments can give social return and financial return as well as generate economic growth of the country (Mean=3.56). Therefore, overall, the IFI employees are aware of the SFIs and the need to provide affordable financing through the SFIs that are Shariah-compliant.

Table 4. Mean Scores of Awareness on Social Finance Instruments (SFIs)

\begin{tabular}{lcccc}
\hline Statement & N & Sum & Mean & SD \\
\hline $\begin{array}{l}\text { Islamic Financial Institutions need to provide affordable } \\
\text { financing through Social Finance Instruments that are Shariah- } \\
\text { compliant }\end{array}$ & 94 & 345 & 3.67 & .753 \\
$\begin{array}{l}\text { Social Finance Instruments can give social return and financial } \\
\text { return as well as generate economic growth of the country }\end{array}$ & 94 & 335 & 3.56 & .784 \\
$\begin{array}{l}\text { I know the purpose of using Social Finance Instruments } \\
\text { I know the functions of using Social Finance Instruments }\end{array}$ & 94 & 330 & 3.51 & .772 \\
$\begin{array}{l}\text { I had heard of the purpose of Social Finance Instruments before } \\
\text { I contributed or invested }\end{array}$ & 94 & 330 & 3.51 & .744 \\
$\begin{array}{l}\text { The functions of Social Finance Instruments include collecting } \\
\text { and keeping the money for the purpose of financial return }\end{array}$ & 94 & 326 & 3.47 & .758 \\
$\begin{array}{l}\text { I had heard of the functions of Social Finance Instruments } \\
\text { before I contributed or invested }\end{array}$ & 94 & 325 & 3.46 & .743 \\
\begin{tabular}{l} 
All Statements \\
\hline
\end{tabular} & & & 3.521 & .659 \\
\hline
\end{tabular}




\subsection{Knowledge of Social Finance Instruments}

Table 5 presents the means and standard deviations of scores on knowledge about SFIs by the respondents, arranged in descending order of size (declining agreeability). The overall mean score of 3.64 indicates that, on average, the respondents indicate a more positive level of knowledge about SFIs, closer to 'agree' on the Likert scale. From the table above, the respondents agreed that support from IFIs could ensure positive impacts towards social returns of the SFIs (Mean=3.76).

This is followed by an agreement with the statements that Using Social Finance Instruments would give the potential for global growth (Mean=3.71) and Social Finance Instruments were introduced for the purpose of financial returns towards the development of the country (Mean=3.60). The respondents also agreed with the statements Social Finance Instruments were introduced to solve society's challenges and Using Social Finance Instruments is the way to solve problems during economic crisis (Mean=3.61 each).

Table 5. Mean Scores of Knowledge on Social Finance Instruments (SFIs)

\begin{tabular}{|c|c|c|c|c|}
\hline Statement & $\mathrm{N}$ & Sum & Mean & SD \\
\hline Support from Islamic Financial Institutions can ensure that & & & & \\
\hline $\begin{array}{l}\text { Social Finance Instruments give positive impacts towards social } \\
\text { returns }\end{array}$ & 94 & 353 & 3.76 & .743 \\
\hline $\begin{array}{l}\text { Using Social Finance Instruments would give the potential for } \\
\text { global growth }\end{array}$ & 94 & 349 & 3.71 & .757 \\
\hline Social Finance Instruments create value for society in the future & 94 & 346 & 3.68 & .793 \\
\hline $\begin{array}{l}\text { Social Finance Instruments create value for the environment in } \\
\text { the future }\end{array}$ & 94 & 341 & 3.63 & .776 \\
\hline $\begin{array}{l}\text { Social Finance Instruments were introduced to solve society's } \\
\text { challenges }\end{array}$ & 94 & 339 & 3.61 & .779 \\
\hline $\begin{array}{l}\text { Using Social Finance Instruments is the way to solve problems } \\
\text { during an economic crisis }\end{array}$ & 94 & 339 & 3.61 & .793 \\
\hline $\begin{array}{l}\text { Social Finance Instruments were introduced for the purpose of } \\
\text { social returns towards the development of the country }\end{array}$ & 94 & 338 & 3.60 & .794 \\
\hline $\begin{array}{l}\text { Social Finance Instruments were introduced for the purpose of } \\
\text { financial returns towards the development of the country }\end{array}$ & 94 & 338 & 3.60 & .807 \\
\hline $\begin{array}{l}\text { Social Finance Instruments introduced are a safe way to support } \\
\text { the needy during economic instability }\end{array}$ & 94 & 332 & 3.53 & .786 \\
\hline All Statements & & & 3.635 & .686 \\
\hline
\end{tabular}

\subsection{Acceptance Level of Social Finance Instruments}

By considering all the nine statements in this section of the questionnaire together, the overall mean score of 3.72 indicates that, on average, the respondents indicate a relatively high positive level of acceptance of SFIs, closer to 'agree' on the Likert scale. Table 6 presents the means and standard deviations of the scores on acceptance level by the respondents, arranged in descending order of size (declining agreeability). From the table above, the respondents agreed with the statements I or We support Social Finance Instruments practice of Islamic Financial Institutions due to knowing that they can give more benefit to the needy and I or We agree that Islamic Financial Institutions are ready to support Social Finance Instruments that are Shariah-compliant (Mean=3.77). This is followed by the agreement to Social Finance Instruments are similar to the Islamic concept of humanism (Mean=3.74), Social 
Finance Instruments are suitable to be practised in Malaysia and I or We agree that Social Finance Instruments will benefit B40 and micro-enterprises in generating economic growth in the future are consistent (Mean=3.72 each). Overall, the results indicate that IFI employees accept that SFIs will benefit the needy and that the instruments need to comply with the Shariah. In the next section, Section 4.6, the relationship between the variables based on the questionnaire is explained.

Table 6 Mean Scores of Acceptance Level to use Social Finance Instruments (SFIs)

\begin{tabular}{lcccc}
\hline Statement & $\mathrm{N}$ & Sum & Mean & SD \\
\hline $\begin{array}{l}\text { I/We support Social Finance Instruments practice of Islamic } \\
\text { Financial Institutions due to knowing that they can give more }\end{array}$ & 94 & 354 & 3.77 & .754 \\
benefit to the needy & & & & \\
$\begin{array}{l}\text { I/We agree that Islamic Financial Institutions are ready to } \\
\text { support Social Finance Instruments that are Shariah-compliant }\end{array}$ & 94 & 354 & 3.77 & .848 \\
$\begin{array}{l}\text { Social Finance Instruments are similar to the Islamic concept of } \\
\text { humanism }\end{array}$ & 94 & 352 & 3.74 & .802 \\
$\begin{array}{l}\text { I/We support Social Finance Instruments practice of Islamic } \\
\text { Financial Institutions due to knowing that they can solve societal }\end{array}$ & 94 & 351 & 3.73 & .819 \\
challenges & & & & \\
$\begin{array}{l}\text { Social Finance Instruments are suitable to be practised in } \\
\text { Malaysia }\end{array}$ & 94 & 350 & 3.72 & .809 \\
$\begin{array}{l}\text { I/We agree that Social Finance Instruments will benefit B40 and } \\
\text { micro-enterprises in generating economic growth in the future } \\
\text { Social Finance Instruments have contributed to the development } \\
\text { of Malaysia's economy }\end{array}$ & 94 & 350 & 3.72 & .709 \\
$\begin{array}{l}\text { I/We support Social Finance Instruments in order to provide } \\
\text { affordable financing to help B40 and micro-enterprises that }\end{array}$ & 94 & 348 & 3.70 & .701 \\
$\begin{array}{l}\text { would give a positive impact on social returns and financial } \\
\text { returns }\end{array}$ & & 344 & 3.66 & .712 \\
$\begin{array}{l}\text { In general, I/we agree that Social Finance Instruments were } \\
\text { introduced to support B40 and micro-enterprises }\end{array}$ & 94 & 342 & 3.64 & .815 \\
All Statements & & & 3.718 & .676 \\
\hline
\end{tabular}

\subsection{Relationship Between Variables}

Correlation analyses were carried out to determine the relationships, if any, between the factors that influence the acceptance of SFIs, namely awareness, knowledge and demography. The summary of the correlation analyses is presented in Table 7. The results are discussed in the following sub-sections. Table 7 shows the results to test the relationships between awareness, knowledge and demographic variables and the acceptance level of IFIs' employees on SFIs. The Pearson correlation and Spearman's rho correlation analyses show that the awareness and knowledge factors have a positive and large correlation with the acceptance level of the IFIs' employees on SFIs $(p<.01)$ meaning that there are strong relationships between the factors for awareness and knowledge and the acceptance level of IFIs' employees on SFIs.

From Table 8, the Spearman rho results show that awareness and knowledge are positively and significantly correlated with the acceptance level of SFIs, whereas demographic factors (age, education level, position and monthly income) are negatively correlated with the acceptance level of SFIs. Non-parametric techniques do not have stringent requirements and do not make assumptions about the underlying population distribution (distribution-free tests). Other than 
that, it is ideal when data that is measured on nominal (categorical) and ordinal (ranked) scales. Table 9 presents the results based on the Chi-square test (nonparametric test). Table 9 shows that awareness and knowledge are significantly associated with acceptance levels of SFIs $(p<.05)$. Whereas, for demographic factors, age and position level are not significantly associated ( $p>.05)$ with the acceptance level of SFIs. However, education level and monthly income are significantly $(\mathrm{p}<.05)$ associated with an acceptable level of SFIs.

Since the data is not normally distributed, the results from the non-parametric analysis are the relevant results. Therefore, it can be concluded that there are significant associations between awareness, knowledge and demography (education level and monthly income) and the acceptance levels of SFIs. However, there is no significant association between the demographic factors of age and position level and the acceptance level of SFIs.

Table 7. Pearson Correlation among Dependent and Independent Variables

\begin{tabular}{cccccccc}
\hline & ACCP & AWR & KNW & AGE & EDU & PST & INC \\
\hline ACCP & 1 & \multicolumn{7}{c}{ Social Finance Instruments (SFIs) } \\
AWR & $.602^{* *}$ & 1 & \multicolumn{1}{c}{} & & \\
KNW & $.805^{* *}$ & $.667^{* *}$ & 1 & & & & \\
AGE & -.094 & .026 & -.074 & 1 & & & \\
EDU & -.132 & .063 & .045 & -.059 & 1 & & \\
PST & $-.313^{* *}$ & -.194 & -.095 & $-.226^{*}$ & $.549^{* *}$ & 1 & \\
INC & $-.245^{*}$ & $-.210^{*}$ & $-.245^{*}$ & $.363^{* *}$ & -.100 & -.083 & 1 \\
\hline
\end{tabular}

Table 8. Spearman rho Coefficient Correlation among Dependent and Independent Variables

\begin{tabular}{cccccccc}
\hline & ACCP & AWR & KNW & AGE & EDU & PST & INC \\
\hline ACCP & 1 & \multicolumn{7}{c}{ Social Finance Instruments (SFIs) } \\
AWR & $.511^{* *}$ & 1 & \multicolumn{7}{c}{} & & \\
KNW & $.786^{* *}$ & $.611^{* *}$ & 1 & & & & \\
AGE & -.056 & .078 & -.079 & 1 & & \\
EDU & -.095 & .088 & .096 & -.026 & 1 & 1 & \\
PST & $-.356^{* *}$ & $-.206^{*}$ & -.080 & $-.225^{*}$ & $.534^{* *}$ & 1 & \\
INC & -.107 & -.181 & $-.204^{*}$ & $.392^{* *}$ & -.172 & -.172 & 1 \\
\hline
\end{tabular}

AWR=Awareness, KNW=Knowledge, AGE=Age, EDU=Education, PST=Position, INC=Income $* *, *$ Correlation is significant at the .01 level $(2$-tailed) $(p<.01)$ and the .05 level $(2$-tailed $)(p<.05)$

Table 9. Summary Chi-Square Tests for Independences

\begin{tabular}{lcc}
\hline Factors & \multicolumn{2}{c}{ Acceptance Level of SFIs } \\
\cline { 2 - 3 } & Chi-Square Tests & $p$-value \\
\hline Awareness & $468.427(99.4 \%<5)$ & .000 \\
Knowledge & $825.396(99.8 \%<5)$ & .000 \\
Age & $53.107(93.7 \%<5)$ & .080 \\
Education Level & $103.333(96.2 \%<5)$ & .041 \\
Position Level & $61.652(67.6 \%<5)$ & .417 \\
Monthly Income & $10.938(96.4 \%<5)$ & .001 \\
\hline$p$-value $<.05$ & &
\end{tabular}




\subsection{Regression Analysis}

Additionally, in this study, simple multiple regression was performed to illustrate the nature of the relationship between the dependent variable and several independent variables chosen for testing hypotheses. As quoted by Pallant, (2011 p. 149) "Multiple regression tells you how much of the variance in your dependent variable can be explained by your independent variables. It also gives you an indication of the relative contribution of each independent variable. Tests allow you to determine the statistical significance of the results, in terms of both the model itself and the individual independent variables". The regression equation below summarises the variables involved to achieve the research objectives in this study.

$\mathrm{ACPT}_{\mathrm{j}}=\beta_{0}+\beta_{1} \mathrm{AWR}_{\mathrm{j}}+\beta_{2} \mathrm{KNW}_{\mathrm{j}}+\beta_{3} \mathrm{AGE}_{\mathrm{j}}+\beta_{4} \mathrm{EDU}_{\mathrm{j}}+\beta_{5} \mathrm{PST}_{\mathrm{j}}+\beta_{6} \mathrm{INC}_{\mathrm{j}}+\sum_{\mathrm{j}}$

Where,

ACPT $=$ Total Acceptance of SFIs

$\mathrm{AWR}=$ Awareness

KNW=Knowledge

$\mathrm{AGE}=1$ if the age younger than 46 years old; 0 otherwise

$\mathrm{EDU}=1$ if the Education Level is Bachelor or higher; 0 otherwise

$\mathrm{PST}=1$ if the Position Level is Manager and above; 0 otherwise

INC $=1$ if Monthly Income is lower than RM30,000; 0 otherwise

$\sum_{\mathrm{j}}=$ Error term

$\beta_{1}=.081$ indicates that, on average, awareness will increase the acceptance level of SFIs by a factor of .081. The $\beta$ coefficients of all other independent variables show positive values, indicating that they increase the acceptance level of SFIs. Based on the coefficients shown in Table 10, the regression equation for this study can be written as:

Table 10. Estimated Regression Equations. Dependent Variable: Acceptance Level of IFIs on SFIs

\begin{tabular}{|c|c|c|}
\hline \multirow[t]{2}{*}{ Factors } & \multicolumn{2}{|c|}{ Acceptance Level SFIs } \\
\hline & Coefficient & $p$-value \\
\hline Awareness & .081 & .335 \\
\hline Knowledge & .730 & .000 \\
\hline Age & .113 & .265 \\
\hline Education Level & .117 & .226 \\
\hline Position Level & .276 & .041 \\
\hline Monthly Income & .079 & .490 \\
\hline Constant & & \\
\hline F-value & & \\
\hline $\mathrm{p}$-value for F-test & & \\
\hline $\mathrm{R}^{2}$ & & \\
\hline Adjusted $\mathrm{R}^{2}$ & & \\
\hline
\end{tabular}

$$
\begin{aligned}
\mathrm{ACPT}_{\mathrm{j}}= & .539+.081 \mathrm{AWR}_{\mathrm{j}}+.730 \mathrm{KNW}_{\mathrm{j}}+.113 \mathrm{AGE}_{\mathrm{j}}+.117 \mathrm{EDU}_{\mathrm{j}}+276 \mathrm{PST}_{\mathrm{j}} \\
& +.079 \mathrm{INC}_{\mathrm{j}}+\sum_{\mathrm{j}}
\end{aligned}
$$

The present high correlation of knowledge with acceptance $(\mathrm{r}=.730)$ would seem to signal multicollinearity issues. Thus, collinearity analysis was carried out 
on all the variables to determine the existence of multicollinearity. The tolerance and VIF values indicate the degree to which the other independent variables explain one independent variable. The common cut-off value for multicollinearity is a tolerance of less than .10 or VIF above 1 . In this case, the analysis showed that there was no multicollinearity issue between the variables. Knowledge has Tolerance $=.531$, which is not less than .10 , therefore, there is no violation of the multicollinearity assumption. This is supported by VIF $=1.883$, which is below the cut-off value of 1 . Although the estimation of the regression coefficients may be unstable, multicollinearity does not affect the reliability forecast since it is not a serious issue if the purpose of the study was to predict or forecast future values of the dependent variable (Sekaran \& Bougie, 2016). Since $r^{2}$ adj $=.683$, this indicates that an equivalent of 68.3 per cent of the variation in the acceptance level of SFIs can be explained by variations in awareness, knowledge, age, education, position, and monthly income, taking into account the sample size and number of independent variables. There is evidence that knowledge and position level variables affect the acceptance level of Social Finance Instruments (SFIs) at $a=.05$, since the $\mathrm{p}$-value is less than $.05(\mathrm{p}<.05)$; whereas, the other variables do not affect the acceptance level of SFIs at $a=.05$, since the $p$-value is more than .05 ( $p>.05)$. In conclusion, the knowledge and position level of the IFI employees affects their acceptance level of SFIs. The results also show that the IFI employees are knowledgeable or understand SFIs practices, especially among those in managerial positions. Therefore, the findings from the regression analysis tended to reject only one hypothesis; i.e. H1: There is a relationship between the awareness of IFI employees and their acceptance of SFIs.

\section{Conclusion}

The results from the analyses in Section 4 showed that the respondents from the IFIs mainly agree that SFIs will give benefits to the needy and need to be Shariahcompliant. This is consistent with Jaffar and Musa (2016) who stated that Islamic finance involves Muslim and non-Muslim consumers and the concept has been accepted globally. The point has also been made by Aziz and Mohamad (2016) that Islamic social businesses, through the waqf, zakat, and sadaqah models, can be used to alleviate social inequality, social problems and poverty efficiently. Jones (2010) opined that community acceptance of SFIs would frequently result in the success of multidimensional plans and projects.

Razinah, Zain, and Adawiah (2017) obtained similar outcomes and said that SFIs that are Shariah-compliant provide social-based financing investments which benefit the society at large as well as the individual. Thus, SFIs such as waqf, sadaqah and zakat can be tools to provide affordable financing to B40 and microenterprises. IFI employees accept that SFIs that comply with the Shariah can be offered to the under-privileged and support a real economy. SFIs such as waqf, zakat, and sadaqah, are tools that provide affordable financing to the B40 and microenterprises as well as offering societal benefits and overcoming societal challenges. With regards to the acceptance level of IFIs' employees of the SFIs concept, there is a significant and robust relationship between awareness and acceptance level of IFI employees towards the SFIs. In other words, IFI employees would be more ready to accept the SFIs when they have a greater awareness of the 
instruments. This is in line with Shaikh et al. (2017) who suggested that it is important to create social awareness before creating the right kind of alternative instruments at the right place. The awareness about the progress made and actions needed to end poverty would develop people's thinking about their lives and raise expectations about what is possible in the future (World Bank, 2017). Awareness will facilitate the process of shaping the broader development of the finance community (Roose \& Bishnoi, 2012).

Apart from that, Samad (2014) stated in his article that awareness campaigns are important to reduce poverty, empower people financially, and inculcate a culture of savings among the people. This is also suggested by World Bank (2016), which mentioned that banks need to implement various strategies to ensure that their senior management is aware of the impacts of the procurement activities which would enable them to address their fiscal, social, and environmental impacts simultaneously. Furthermore, Jones (2010), in his article, stated that awareness is important due to the diverse nature of institutions that exist in human societies and it would lead to an understanding of the mechanisms which allow community collaboration. Haneef et al. (2013) argued that, for acceptance purposes, awareness about the existence and nature of Islamic microfinance must be created in advance among the recipients of microfinance. In the context of this study, awareness among the employees of IFIs must be created in advance for the concept of SFIs to be readily acceptable to the IFI employees. Hassan (2014), for example, found that the level of awareness will uplift Islamic microfinance groups and potential management through the united action of the groups. In short, the findings of this study are similar to findings of previous researchers mentioned earlier.

Awareness enables IFI employees to address their social, fiscal, and environmental impacts simultaneously. The employees are more ready to accept SFIs when they are more aware of the instruments and this, in turn, leads to the achievement of the objective. Next, findings of this study also revealed that knowledge has a strong and significant relationship with the acceptance level of IFI employees of the SFIs. The respondents generally know that support from IFIs can ensure that the SFIs will have positive impacts on social returns. More knowledge about the SFIs will give a better acceptance of the instruments as affordable financing for the B40 and micro-enterprise. This is in line with the study by Fianto et al. (2017) who showed that clients' knowledge of Islamic microfinance had a significant impact on the clients' income. In other words, knowledge and understanding of IFI products are essential to ensure that consumers can accept the products. Perren (2000) pointed out that, with knowledge, a person will be able to think creatively towards growth opportunities. Likewise, Alessia and Boiardi (2017) mentioned that relevant knowledge is needed in order to tackle societal challenges, make use of public resources more effectively and promoting more sustainable and environmental-friendly growth. They supported Gait and Worthington (2008) who believed that knowledge aids the decision making of policymakers, consumer interest groups, business companies and financial institutions. Therefore, the findings of this study on the relationship of knowledge with an acceptable level of SFIs are in accordance with many of the previous studies mentioned earlier. It is important to acquire knowledge or understanding 
which can influence the acceptance of the SFI concept so that it can be applied in the IFIs. The knowledge among the IFI employees has strong and significant relationship with the acceptance of SFIs, which encourages the provision of affordable financing to the B40 and micro-enterprises.

This study has focused on employees' acceptance that needs knowledgeable and skillful employees to contribute to a positive environment of an organisation so that they can assist in realising the organisation's objectives. Reasons for examining the demographic profile are associated with the objective since individuals may have different perceptions towards certain things depending on their particular demographic background (Fianto et al., 2017). However, the results discussed in Section 4 indicated that acceptance among IFI employees in using SFIs has a weak relationship with demographic factors (age, education level, position level and monthly income). Only the education level and monthly income had significant relationships with the acceptance level of IFI employees towards using SFIs. However, the findings also showed that the managerial position had a significant effect on the acceptance level of the SFI employees. The results are in line with a study by Sherif and Azlina (2013) who found that income level and education level were the most significant factors related to the demand for takaful, which is one of the Islamic SFIs. McCannon (2014) also highlighted that education in finance promotes pro-social choices that generate wealth, even when external incentives are absent.

In using the demographic profile to measure acceptance level of IFI employees on SFIs as a tool to provide affordable financing to B40 and micro-enterprises, this study is similar to Samad (2014) who included the respondents' demographic profile to measure the willingness of respondents to deal with the IMF. In addition, Al-sultan (1999), in his study, discovered that age, income, and occupation played significant roles in individuals' decisions about which banking system to choose in Kuwait. Many other studies (e.g. Milfont \& Gouveia, 2006; Paetzold et al., 2015; Ostrom et al., 2010; and Cheah \& Phau, 2011) have highlighted that their dependent variables are affected by socio-demographic variables such as age, and education level. Therefore, from the analysis on the demographic variables in this study, it can be said that education level and monthly income have a more significant influence on the acceptance of SFIs than age and position level, and these findings concur with those of Sherif and Azlina (2013) and McCannon (2014). Findings from the study are also consistent with the Theory of Planned Behaviour, where an individual's actions and decisions are influenced by their knowledge.

This study is subject to some limitations despite the efforts made by the researcher. First, the time constraint during the process of distributing and collecting the questionnaires from the respondents limited the number of recipients giving their feedback and hence, reduced the amount of data derived from the questionnaires. The time constraint also inhibited the ability of the researcher to assist some recipients who had difficulty in answering the questionnaire which, in turn, further reduced the number of completed questionnaires received. Second, it was not easy to receive the responses from the IFI employees promptly because the questionnaires were distributed during working hours when they were also dealing with customers, and this lengthened 
the time needed to complete the questionnaires. Therefore, it is recommended that the study be repeated using samples from other IFIs throughout Malaysia to gain more generalisable findings. The respondents could also be diversified to include investors, educators, and others related to SFIs. Since the current study was adapted, with some modifications, from a few previous studies and only concentrated on the zakat, waqf and sadaqah, this study excluded SFIs in the form of equity or debt financing, co-operative investment, microfinance and social impact bonds. Future studies could enhance their attributes to include these items. During the final stage of analysis, the classification of income was grouped into two categories, i.e. above RM30,000 and below RM30,00. This was to ensure the multiple regression analysis could be performed using dummy variables. Future studies could include more dummy variables to represent more income groups. Additionally, no control variable was included in this study because the application of SFIs is still in its initial stages in Malaysian IFIs; future studies could include any control variables that have contributed an effect on the results.

Lastly, only three factors that can influence the acceptance level were analysed; namely, (i) awareness, (ii) knowledge, and (iii) demography. Hence, it is suggested that other factors, such as policymakers and governments could be included in future studies. Other than the limitations, there are weaknesses in this study due to using quantitative techniques. According to Choy (2014), the weaknesses of using a quantitative research approach are: (i) there is data related to beliefs and perceptions from the human aspects, (ii) lack of resources when a large scale study is involved, and (iii) there is no description of in-depth experience. A future study could include qualitative data.

\section{References}

Abuarqub, M., \& Phillips, I. (2009). A brief history of humanitarianism in the Muslim world. Islamic Relief Worldwide, (July). Retrieved from http:/ / policy.islamic-relief.com/

Ahmad, S.Z. (2012). Micro, small and medium-sized enterprises development in the Kingdom of Saudi Arabia. World Journal of Entrepreneurship, Management and Sustainable Development, 8(4), 217-232. https:// doi.org/10.1108/20425961211276606

Al-sultan, W. (1999). Financial characteristics of interest-free banks and conventional banks. University of Wollongong Research Online, 1-241. Retrieved from https://ro.uow.edu.au/theses/1019

Alessia, G., \& Boiardi, P. (2017). Financing for social impact: The key role of tailored financing and hybrid finance. Retrieved from https:/ / evpa.eu.com/

Aziz, N.M., \& Mohamad, O.B. (2016). Islamic social business to alleviate poverty and social inequality. International Journal of Social Economics, 43(6), 573-592. https:/ / doi.org/10.1108/IJSE-06-2014-0129

Bank Islam Malaysia Berhad (BIMB). (2017). Bank Islam Malaysia Berhad Annual Report 2017, 147. Retrieved from http:// www.tigerbrands-online.co.za/

Bank Negara Malaysia. (2018a). Islamic Bank in Malaysia. Retrieved from http://www.bnm.gov.my/

Bank Negara Malaysia. (2018b). Value-Based Intermediation: Strengthening the roles and impact of Islamic Finance, (March). Retrieved from https://www.bnm.gov.my/

Benedikter, R. (2011). Social Banking and Social Finance-Answers to the Economic Crisis. New York, NY: Springer.

Cheah, I., \& Phau, I. (2011). Attitudes towards environmentally friendly products: The influence of ecoliteracy, interpersonal influence and value orientation. Marketing Intelligence and Planning, 29(5), 452-472. https://doi.org/10.1108/02634501111153674 
Choy, L.T. (2014). The Strengths and Weaknesses of Research Methodology: Comparison and Complimentary between Qualitative and Quantitative Approaches. Journal of Humanities and Social Science, 19(4), 99-104. https:// doi.org/10.9790/0837-194399104

D'Ortenzio, C. (2012). Understanding Change and Change Management Processes: A Case Study. (Doctoral Thesis). University of Canberra Canberra, Australia.

Department of Statistics Malaysia. (2017). Department of Statistics Malaysia Press Release Report of Household Income and Basic Amenities Survey 2016. Report of Household Income and Basic Amenities Survey 2016. https:// doi.org/1.1017/CBO9781107415324.004

Department of Statistics Malaysia. (2018a). Consumer Price Index (CPI). Indeks Harga Pengguna.

Department of Statistics Malaysia. (2018b). Demographic Statistics Second Quarter (Q2), 2018, Malaysia.

Department of Statistics Malaysia. (2018c). Department of Statistics Malaysia Press Release.

Economic Planning Unit. (2016). Incidence Poverty Ethnic Group Strata and State of Malaysia in 1970 to 2016. Retrieved from http://www.epu.gov.my/

Fianto, B.A., Gan, C., Hu, B., \& Roudaki, J. (2017). Equity financing and debt-based financing: Evidence from Islamic microfinance institutions in Indonesia. Pacific Basin Finance Journal, 52, 163-172. https://doi.org/10.1016/j.pacfin.2017.09.010

Gait, A.H., \& Worthington, A.C. (2007). A Primer on Islamic Finance: Definitions, Sources, Principles and Methods. Faculty of Business, Accounting \& Finance. University of Wollongong, Working Papers in Accounting and Finance, No. 07/05. Retrieved from https://ro.uow.edu.au/accinwp/5

Gait, A., \& Worthington, A. (2008). An empirical survey of individual consumer, business firm and financial institution attitudes towards Islamic methods of finance. International Journal of Social Economics, 35(11), 783-808. https:// doi.org/ 10.1108/03068290810905423

Global Impact Investing Network. (2018). Annual impact investor survey 2017: The seventh edition. The Global Impact Investing Network (GIIN). Retrieved from https:/ / thegiin.org/

Haneef, M.A., Pramanik, A.H., Mohammed, M.O., Dahiru, A., \& Amin, F. (2013). Integration of Waqf and Islamic Microfinance for Poverty Reduction: A Survey in Kuala Selangor, Malaysia. Journal of Islamic Finance, 2(2), 1-16. Retrieved from https://journals.iium.edu.my/iiibfjournal/index.php/jif/article/view/16

Hassan, A. (2014). The challenge in poverty alleviation: Role of Islamic microfinance and social capital. Humanomics, 30(1), 76-9. https:// doi.org/10.1108/H-10-2013-0068

Hill, R. (1998). What sample size is "ENOUGH" in internet survey research. Interpersonal Computing and Technology: An Electronic Journal for the 21st Century, 6, 3-4.

Jaffar, M.A., \& Musa, R. (2016). Determinants of Attitude and Intention towards Islamic Financing Adoption among Non-Users. Procedia Economics and Finance, 37(16), 227-233. https:// doi.org/10.1016/S2212-5671(16)30118-6

Jones, J.F. (2010). Social finance: Commerce and community in developing countries. International Journal of Social Economics, 37(6), 415-428. https:// doi.org/10.1108/03068291011042300

Khan, A.A., Tahmazov, I., \& Abuarqub, M. (2009). Translating Faith into Development. Birmingham, UK: Islamic Relief Worldwide. Retrieved from http://chede.org/

Linder, F., \& Wald, A. (2011). Success factors of knowledge management in temporary organizations. International Journal of Project Management, 29(7), 877-888. https://doi.org/10.1016/j.ijproman.2010.09.003

McCannon, B.C. (2014). Finance education and social preferences: Experimental evidence. Journal of Behavioral and Experimental Finance, 4, 57-62. https://doi.org/10.1016/j.jbef.2014.10.001

Milfont, T.L., \& Gouveia, V.V. (2006). Time perspective and values: An exploratory study of their relations to environmental attitudes. Journal of Environmental Psychology, 26(1), 72-82. https://doi.org/10.1016/j.jenvp.2006.03.001

Montargot, N., \& Lahouel, B.B. (2018). The acceptance of technological change in the hospitality industry from the perspective of front-line employees. Journal of Organizational Change Management, 31(3), 637-655. https:// doi.org/10.1108/JOCM-10-2016-0192

Muda, I., Rafiki, A., \& Harahap, M.R. (2014). Factors Influencing Employees' Performance: A Study on the Islamic Banks in Islamic Science University of Malaysia University of North Sumatera. International Journal of Business and Social Science, 5(2), 73-81. Retrieved from https://ijbssnet.com/journal/index/2360 
Mustapa, W.N.W., Mamun, A.A., \& Ibrahim, M.D. (2018). Economic Impact of Development Initiatives on Low-Income Households in Kelantan, Malaysia. Social Sciences, 7(7), 1-17. https://doi.org/10.3390/socsci7070118

Oseni, U.A., Adewale, A., \& Zain, N.R.B.M (2016). Customers' perceptions on the dispute resolution clauses in Islamic finance contracts in Malaysia. Review of Financial Economics, 31, 89-98. https:// doi.org/10.1016/j.rfe.2016.05.004

Ostrom, A.L., Bitner, M.J., Brown, S.W., Burkhard, K.A., Goul, M., Smith-Daniels, V., \& Rabinovich, E. (2010). Moving forward and making a difference: Research priorities for the science of service. Journal of Service Research, 13(1), 4-36. Retrieved from https://doi.org/10.1177/1094670509357611

Paetzold, F., Busch, T., \& Chesney, M. (2015). More than money: exploring the role of investment advisors for sustainable investing. Annals in Social Responsibility, 1(1), 195-223. https:// doi.org/10.1108/ASR-12-2014-0002

Pallant, J. (2011). SPSS Survival Manual: A step by step guide to data analysis using SPSS (4th Ed.). Milton Keynes, UK: Open University Press

Park, N., Rhoads, M., Hou, J., Lee, K.M. (2014). Understanding the acceptance of teleconferencing systems among employees: An extension of the technology acceptance model. Computers in Human Behavior, 39, 118-127. https:/ / doi.org/10.1016/j.chb.2014.05.048

Perren, L. (2000). Factors in the growth of micro-enterprises (Part 2): exploring the implications. Journal of Small Business and Enterprise Development, 7(1), 58-68. https:// doi.org/10.1108/EUM0000000006805

Radun, I., Nilsonne, G., Radun, J., Helgesson, G., \& Kecklund, G. (2019). Company employees as experimental participants in traffic safety research: Prevalence and implications. Transportation Research Part F: Traffic Psychology and Behaviour, 60, 81-92. https://doi.org/10.1016/j.trf.2018.10.008

Razinah, N., Zain, M., \& Adawiah, E.R. (2017). An Analysis on Islamic Social Finance for Protection and Preservation of An Analysis on Islamic Social Finance for Protection and Preservation of Maqāṣ id al- Sharī'ah. Journal of Islamic Finance, (January 2018), 133-141. https://doi.org/1.12816/0047345

Rizzi, F., Pellegrini, C., \& Battaglia, M. (2018). The structuring of social finance: Emerging approaches for supporting environmentally and socially impactful projects. Journal of Cleaner Production, 170, 805-817. https:// doi.org/10.1016/j.jclepro.2017.09.167

Roose, N., \& Bishnoi, K. (2012). The Sovereign Wealth Fund Initiative Fall 2012 Defining an Ecosystem for Social Finance. The Fletcher School Tufts University. Retrieved from https://sites.tufts.edu/

Samad, M.A. (2014). Islamic micro finance: Tool for economic stability and social change. Humanomics, 30(3), 199-226. https:/ / doi.org/10.1108/H-12-2013-0085

Scharrer, B. (2015). Employees' Acceptance and Involvement in Accordance with Codes of Conduct - Chinese Business Behaviour vs. Western Compliance Management Systems. Procedia Social and Behavioral Sciences, 213, 855-859. https://doi.org/ 10.1016/j.sbspro.2015.11.495

Sekaran, U., \& Bougie, R. (2016). Research Methods for Business (7th Ed.). United Kingdom: John Wiley \& Sons Ltd.

Shaikh, S.A. (2017). Poverty alleviation through financing microenterprises with equity finance. Journal of Islamic Accounting and Business Research, 8(1), 87-99. https:// doi.org/10.1108/JIABR-07-2013-0022

Shaikh, S.A., Ismail, A.G., \& Shafiai, M.H.M. (2017). Application of waqf for social and development finance. ISRA International Journal of Islamic Finance, 9(1), 5-14. https:// doi.org/10.1108/IJIF-07-2017-002

Sherif, M., \& Shaairi, N.A. (2013). Determinants of demand on family Takaful in Malaysia. Journal of Islamic Accounting and Business Research, 4(1), 26-50. https://doi.org/10.1108/17590811311314276

Social Finance Organization in United Kingdom. (2017). Acknowledgement. Retrieved from https://www.socialfinance.org.uk/ 
Tayal, R., Upadhya, R.K., Yadav, M., Rangnekar, S., \& Singh, R. (2018). The impact of transformational leadership on employees' creativity. Management Research Review, 41(1), 113132. https:// doi.org/10.1108/JABS-03-2014-0022

Thaker, M.A. (2018). A qualitative inquiry into cash waqf model as a source of financing for micro enterprises. ISRA International Journal of Islamic Finance, 10(1), 19-35. https:/ / doi.org/10.1108/IJIF-07-2017-0013

World Bank. (2016). The World Bank Annual Report 2016. Retrieved from http://documents.worldbank.org/

World Bank. (2017). End Extreme Poverty, Boost Shared Prosperity: The World Bank Annual Report 2017. Retrieved from https://openknowledge.worldbank.org/

World Bank. (2018). Decline of Global Extreme Poverty Continues but Has Slowed: World Bank. Retrieved from http://www.worldbank.org/

Zain, N.R.M., \& Ali, E.R.A.E. (2017). An Analysis on Islamic Social Finance for Protection and Preservation of Maqāṣ id al-Sharī' ah. Journal of Islamic Finance IIUM Institute of Islamic Banking and Finance, 6, 133-141. Retrieved from https://journals.iium.edu.my/iiibfjournal/index.php/jif/article/view/262

Ziyaad, M. (2017). The Islamic Social Finance \& Investment Imperative. Centre for Islamic Asset and Wealth Management, 29-31. Retrieved from http://www.inceif.org/ 